\title{
A Review-Halal Animal Nutrition Perspective to the Halal Meat Production
}

\author{
Aamir Iqbal*, Syed Rizwan Ali Shah, Ibrahim Sadi Cetingul, Abdul qudoos, Ismail Bayram \\ Department of Animal Nutrition and Nutritional Diseases, Faculty of Veterinary Medicine, Afyon Kocatepe University, Afyonkarahisar, Turkey \\ *Corresponding author e-mail: aamir_vet @ yahoo.com
}

\section{Doi: 10.2478/mjhr-2020-0003}

\begin{abstract}
:
This review tends to analyze the importance of halal animal feed from the Islamic standpoint and describes the drawbacks of non-halal. Mischievousness to animal handling during production, transport, and slaughter in states where Islam is the main doctrine has created doubts about the quality of products. Islam is a religious conviction that illustrates empathy to animals and well-being of humankind food as mentioned in the holy book Qur'an and sayings of the Prophet Mohammed (PBUH). In a variety of animal-based halal food products, a Muslim should be conscious of not only about the rearing organization of the animals but also the slaughtering procedure. Animal feed is the preliminary Critical Control Point to establish the halal authenticity of animal-based food products. Regardless of the recognized agenda on animal feed in Middle East Asia, impurity in animal feed ingredients is still occurring and repetitively reported by the media. Feed inflicts direct effect on the animal originated feedstuffs like meat, milk, and eggs and it has been acknowledged as the foremost cause of diseases in both humans as well as animals. Consequently, any action that is associated with the production of livestock must be intimately explored to spot any vulnerability with liable Islamic laws of food and hit upon those traditions to avoid them. The intent of this review is to appraise the halal nutritional system of animals and see whether it has any optimistic or depressing effects on the health of the customers. Our advancement will be comprehensive as we have focused on the socio-religious aspects of human health. The verdict of this review could be made as an orientation by the policymakers of emerging officially authorized business bodies for producing, importing and auction of halal animal feed according to Islamic set of guidelines.
\end{abstract}

Keywords: Socio-religious aspects, feed ingredients, Islamic laws, halal nutritional.

\subsection{Halal Meat: Islamic prospective}

The increment in the muslim inhabitants has introduced the term halal all around the globe [1]. The ignorance about halal in non-Muslim communities has made the grade of imported products hesitant for Muslim countries [2,3]. The most remarkable merchandise due to the fixed requirements is halal meat [4]. Halal meat wastes its halal-ness as shortly as it becomes tainted with najis (unclean) [5]. Undeniably, it is vital to recognize the requirements and laws of halal food, which faces spiritual aspects [6]. The motive for Muslims to monitor these food laws are to pursue the Heavenly amendments and orders by Allah [3].

"And depart what is obvious of sin and what is deemed thereof. Certainly, those who make (blame for) offense will be rewarded for that which they used to hand over." Holy Quran

"So eat of that (Meat) upon which the surname of Allah has been cited if you are a supporter in His Ayyat." Holy Quran

"Allah has only prohibited to you deceased animals, blood, swine, and that which has been devoted to other than Allah. But whoever is strained (by necessity), neither longing (it) nor disobeying (its limit), there is no sin upon him. Undeniably, Allah is Pardoning and Compassionate." Holy Quran "Oh! you who have believed, eat from the fine things which We have made available to you and be appreciative to Allah if it is (Indeed) Him that you worship "Holy Quran- 2:172

Feed comprises $60-70 \%$ of the entire expenditure of livestock production and poultry is the foremost intensive livestock industry while ruminant production is extensive and semi-intensive and utilizes the pasture-based green forages and accessible [7]. In middle-east countries, there is the importation of about $60-70 \%$ of the feedstuffs like maize grains, soybean, and its meal and these are the major poultry feed elements [8]. Contrary to this the ruminants mainly use locally available stuff like Palm Kernal Cake (PKC) and agro-industrial by-products [9]. The farmer fed animals with absurd and aberrant feed ingredients due to prevailing issues so-called 'economic considerations' [10]. The indecent feeding practices are said to be the basis for the spread of syndromes in animals which have spoiled hygienic meat production [11,12]. Pig intestines and carcass by-products are used for fish farming by reckless farmers and it leads to aggravation and annoyance among the Muslim society [13]. These fashioned reservations about the validity of such fish and a tangible resolution to this subject matter are required $[14,15]$. The use of growth hormones in bovine (rBST) causes mastitis in cattle and it is found to be the radical cause of colon and breast cancer in the human [16-18]. Increased use of meat and bone meal in ruminant feeding causes Bovine Spongiform Encephalopathy (BSE) in cattle and the animal's meat suffering from this disease is unfavourable for human consumption $[19,20]$.

Many studies have been conducted on the aspect of supervision, wellbeing, and excellence of animal feed [21]. Some of these studies spotlight on management and certification system convenient in the manufacture of animal feed while other studies categorize the contaminations and hazards related to feeding Most modern studies on animal feed determine the prospective use of locally accessible feed ingredients and acknowledgment of contaminants in animal feed [22-27]. The studies, nevertheless, do not spell out the significance of halal in animal feeding and feed production [28-30].

Animal feed is among the Halal Control Point (HCP) in livestock production systems that need to be evaluated in the halal supply chain to conserve the veracity of the animal-based foodstuffs $[31,32]$. Halal production is declared as the primary Halal Critical Control Point (HCPs) to be evaluated in the halal meat chain and emphasize the value of quarantine practice for an animal that feeds on dung and other animal proteins and by-products [33].

To attain halal and safe products, the state hosts some Annual Halal Weeks which comprises a variety of proceedings such as World Halal Forum (WHF), World Halal Research Summit (WHR) and International Halal Showcase (MIHAS) with the particular intent of intensifying the development of the global Halal commerce through industry harmonizing and trade demonstration [34]. The agenda attracts thousands of participants around the globe [35]. The United Arab Emirate also arranges parallel ceremonies on a more standard basis [36]. Contrasting to the Malaysian events which are held yearly in an impressive mode, Gulf-food proceedings are held in a regular and persistent manner attracting food vendors and entrepreneurs from all around the world. Halal food demonstrations, food leader's culmination, food processing, and packaging and chartered seminars are the featured objectives of these events [37].

\subsection{Rules and Regulations- The Feed Act, 2009}

This was publicized on 3 September 2009 and first came into operation on 1 January 2010. Its rationale was to legalize the feed standard by controlling the halal ingredients' import, production, sale, and utilization of feed additives to guarantee that the feed convinces the nutritional requirements of animals [38]. This ensures that the feed and by-products are free of contamination and are not harmful to animals and the end products from the animals are safe for human consumption. Provided that Islamic decree is ill-assorted with secular business law, Malaysia, the manager of the World Halal Forum, which assemble stakeholders from the halal food market, secured an oath from the Food and Agriculture Organization of the United Nations (FAO) to take account of guidelines for the use of the term halal in the Codex Alimentarius, to guard it from being used incongruously [39]. Being an intercontinental standard, halal has now been absolutely ahead of meat products to water, cosmetics, and pharmaceuticals. It fundamentally concerns to no matter whatever may come into contact with the body [40]. Malaysia had passed the Feed Act 2009 in March 2013 in accordance with the encouragement to declare quality and 
wellbeing of the animal feed and to standardize and legalize the animal feed engineering and assembling of halal ingredients [41]. This act monitors feed worth through scheming importation, manufacture, sale and use of not harmful and contaminated feed and feed additives, with the intention of satisfying nutritional requisites of animals [41]. Federal Government had also reviewed the feed rules and policies in 2012 and 2015 which comprise a set of laws for feed and feed additives assembling and sale authorization, quality analyzing, labeling and importation [42]. The Act illustrates issues linked to animal wellbeing together with farmer responsibilities about rearing, housing, selling and transportation of animals, as well as imposing firm measures to lessen transgression against animals [43]. These laws are implemented in official documentation system form the Department of Veterinary Services, Ministry of Health and other state bodies [44]. Clause 53 (2) of Feed Act 2009 includes the regulations;

1) To recommend the market analyst education, experience, conduct and duties

2) To set down all issues involving appliance, regeneration, postponement, and revocation of the license to import feed ingredients [45]

3) To lay down the terms and limitations of license to import feed ingredients;

4) To fix all problems related to feeding requirements and quality;

5) To advice all problems linked to the labelling and packing; Storage and transport of feed ingredients

6) To recommend all issues about the use of feed additives

7) To control the production, assembling, sale, classified ads about feed;

8) To demonstrate and certificate the analysis of feed;

9) To fix the analysis fees payable according to this Act;

Penalty for First Offence is RM100, 000.00 and 2 yrs. jail (NE) or both and for the Second Offence is RM200, 000.00 and 4 yrs. jail (NE) or both.

\subsection{Animal Feed Accountabilities:}

Concerns related to the exploit of animal by-products from abattoirs wastage is not a novel focus of hot debate [46]. Blood and bones have long been exercised as sky-scraping protein ingredients in animal nutrition with high nutrient worth, low rate and environmentally welcoming [47]. In Muslim countryside, the subject associated with the exploitation of animal by-products has hosted fright on the safety and also the halal veracity of the animal meat [48]. Frequent events of offensive feeding practices are accounted since 2006 by the media in Malaysia. One misuse was reported when animal skulls and bones were spotted at the bottom of the fish pool due to out of order drain line [49]. A few farmers were found guilty of feeding 'Patin' fish with pig bowels in 2013 [50]. Another case happened in Perak after a few months and a whole pig carcass was found to be the nutrition for feeding Tilapia [51]. In livestock feed, pork and its derived chemicals are extensively used materials, such as caproic acid, sodium sterols lactate, whey, pork meal, collagen, calcium stearate, meristic acid, oleic acid, gelatine, pancreatic extract, bone ash, and lard [52].

The use of deceased animal cadaver as minced meat and bone meals is also accounted for fish farming [53]. Common diseases associated with consuming the meat of those animals reared with dead animals meals include; Campylobacter Cryptosporidiosis Escherichia coli infection 0157: H7 and Haemolytic Uremic Syndrome (HUS), Salmonellosis (Salmonella) [54-57]. Blood meal is also being used for fish farming and poultry and ruminant feeding and is found to be inexpensive but in the high amount, it causes loss of production and huge mortality and it carries with itself harmful pathogens [58].

We have to realize that the foundation for the ban of pork in Islam is for healthy existing. Pigs have been documented as a very filthy and infected animal [59]. Above and beyond this, pork has high fat causing pork eaters to be more vulnerable to obesity, blood pressure, aggression, atherosclerosis, cardiovascular accidents, depression, and bad odour from body, anxiety and even sudden death [60]. Besides, it has been technically established that the pig's flesh and skin anchorage some microbes that are hazardous to the human physical condition and no one has been able to build antiseptic methodology of entirely removing these pathogenic parasites and microbes [61].

Trichinella Spralis (Trichia worms), Taenia Solium (Pork tapeworm), Round Worm (e.g Ascaris causing obstructive jaundice), Hook Worm (e.g Ancylostomiasis - causing anaemia, oedema, heart failure, retarded growth, tuberculosis, typhoid and diarrhoea), Schistosoma japonicum (causing bleeding, anaemia etc), Paragomines Westermeini (causing bleeding in the lungs called endive hemoptysis), Pasiolepsis Buski (causing diarrhoea and oedema), Clonorchis Sinensis (causing obstructive jaundice and liver enlargement), Metastrongylus Aspri (causing bronchitis and abscess of the lungs), Gigathorinchus Gigas (causing digestive disorder and anaemia), Balatitidium Coli (causing acute dysentery and general weakness), high prevalence of a Non-Tuberculosis Mycobacteria (NTM) and toxoplasma gondi are some parasites that are found in pork meat [62]. Moreover, ruminants and poultry offered pork by-product meals also suffer from diseases and mortality and the meat becomes haram [63-68].

In spite of the constitution of legal and regulatory agenda on animal feed in Muslim states, a very little of the legislation deals with the concerns of halal animal feed in terms of its constituents, processing, transportation, and storage [69]. Lacking awareness and publicity on the Sharia standpoint of halal animal are the grounds why some of the feed millers are unaware of the significance of halal feeding for animal production [70]. Therefore, the absences of precise halal strategy relevant to the production of halal animal feed are thought to be one of the reasons characteristic of the inappropriate feeding and dishonesty in animal feed production [43].

\subsection{Islamic Declaration on Animal Feed:}

The feeding of animals by najis material is an old practice and it has long been argued by Muslims scholars, and they have divided the arguments into two groups; feeding the edible and the non-edible animals [71]. According to Hanbalites and Malikites, the non-edible animals are permitted to be fed with nonhalal feed. The views are based on the fact that animals such as dog, cat, and other pets like eagles' are not meant for consumption, thus it is not haram to feed because of the scarcity of halal food for Muslim's [72].

On the other hand, Muslim scholars state different opinions with regard to the issue of feeding non-halal feed to animals that can be eaten. According to the Hanbali school of thought, animals are allowed to be fed with impurity and filth, if the meats and milk are not to be consumed in a short period of time [73]. This opinion is based on the typical practice in farming, in which livestock are left freely grazing forage and somehow may also eat some filths and impurities in the pastureland [74]. But fatwa from Indonesia and Brunei forbid the production and trade of animal feed that contain swine ingredients or other nonhalal animals. The fatwa of Brunei also dishearten feeding of meat and milk animals with filthy feeds and selling those animals products without suitable quarantine process [75]. The animal is permitted to be consumed by Muslims after keeping them separate from filth feed for almost 40 days.

\subsection{The Al-Jallalah Concept}

Al-jallalah means the class of animals that eat on filth and impurities, time after time, or regularly being fed with dung, which accordingly resulted in the transformation of the animal's aroma, flavor, and tint of the meat [76]. On the other hand, it is essential to remember that animal can only be believed as aljallalah when most of the feed they eat is impure and there are noticeable changes in the physical traits of meat and milk [77]. This is because a few animals normally engulf certain amounts of filth or their own droppings (coprophagia), and this doesn't alter physic-chemical traits of the meat and milk. Cleaning or cooking methods will not remove its legal ruling of makruh, unless the animal gets well to its normal production by quarantine and be fed with uncontaminated feed before slaughter [77]. 
The fashion of feeding meat animals with animal wastes and animal by-products is a widespread tradition in rural areas and has been noticed in many Asian countries. This has initiated an Islamic lawful subject matter and formed doubts among Muslim community due to the absence of obvious answers and solutions. There has been controversy among halal animal feed scenario and the appliance of animal by-products and their extracts into an animal diet including those from swine [51]. Some scholars consider that offering an animal with a feed that contains any fraction of a haram animal is contaminated and forbidden from being slaughtered. Some other scholars believe that an animal that lives in filth and eats foreign matters all the time is categorized as infected and is banned. "Al-jalalah" is a term used to describe animals that always or barely ever eat the waste of other animals, or pigs and its derivatives and a transform occurs in their aroma and flavor. Prophet Mohammed forbade ingestion of the meat and milk from such animals. Nevertheless, the term "Al-jalalah" will not be proficient for those animals that eat from filth and clean feed. Most Muslims believe that the feed for an animal, whether this animal is raised for meat, milk or eggs, must be a plant origin diet. Some other Muslims accept as true that only pork and non-halal animal by-products are outlawed from animal nutrition. For this Saudi Arabia has prohibited the sale and export of animals fed a diet that contains by-products of illegal animals [78].

Assessing the sayings of the Prophet (P.b.u.h) in the Kutub al-Sittah (The Authentic Six), it is found that there are thirteen sayings about the ban of al-jallalah The bans include in riding, eating, and drinking of the milk of the al-jallalah. The ban on riding al-jallalah animals appears in Kitab Al-jihad of Sunan Abu Daud, in the chapter 'Regarding riding al-jallalah' saying number 2557 and 2558. In the saying narrated by Abdullah Ibn 'Umar, the Prophet (P.B.U.H) said; "It has been prohibited to ride the animal which eats dung". And in another saying which also narrated by Abdullah Ibn “Umar, that he said: "The Messenger of Allah (P.B.U.H) prohibited to ride a camel which eats dung". Based on the compilation of both hadith under Kitab al-Jihad, it is applied not to ride aljallalah even for the intention of going to war (jihad). The ban makes obvious eating of such animals, too. Ibnu Umar narrates another saying of prophet P.B.UH in 'Kitab Al-At'imah' of 'Sunan Abu Daud', in the chapter 'The prohibition of eating al-jallalah and its milk', saying number 3785, 3786 and 3787) and 'Sunan Al-Tirmidhi' (hadith number 1824 and 1825). The forbiddance of eating the meat and milk of al-jallalah also found in 'Kitab ad-Dahaya' in the saying number 4452 and 4453 and in the subdivision of Slaughtering of the book 'Sunan Ibn Majah'.

\subsection{Food Biotechnology}

Biotechnology laid a great impact on food commerce as a source of synthetic materials, and innovations [79]. Nowadays genetically modified organism (GMO) vegetables or plants, and use of food additives, enzymes, emulsifiers, and hormones are of major concern for Muslims [80]. Muslim consumers are sensitive to the foodstuffs they use. The novel encroachment and impact of these progressions upon the Islamic nutritional verdict is very imperative [81]

\subsection{Genetic modifications}

Reinstallation of DNA of an organism (maybe plants, vegetables or animals) by taking a gene from one species and inserting it into another discrete species which are not evolutionarily connected, results in the organism called Genetically Modified Organism (GMO).

\subsection{From animals to plants}

This renovation for the more wholesome plant life will be regarded as Halal as long as the source animal is Halal [83]. In the case where the source animal is not Halal, there is a dispute among Muslim scholars. For instance, pork is clearly proclaimed as Haram in Islam. So getting any gene from pork is forbidden even though the end product changes and transferred gene is decoded according to host cell but as it is clearly Haram so any gene or even a codon is taken from it will be Haram [84].

For example, swine cytochrome P450 gene is incorporated into the rice plant and transform products are formed. The rice plant altered with swine CYP2C49 proved resistance to herbicides (National Institute of Agrobiological Sciences, Japan, 2002-07-01). Evidently, these rices become haram for Muslims. Pig DNA in soy makes it Haram for Muslims. The oil or any material extracted and made from that engineered soy either will be Haram or Makrooh so Muslim consumers should avoid it [85].

\subsection{From insects to plants}

A major field of biotechnology in food is the use of microbial "genes or products" in food. The product of gene, in this case, will be considered as Halal because the category of insects is not clearly defined and no intoxicants or harmful effects are found [86].

Some disagreement takes place due to the threat for health, a menace for wildlife, and other animals. Plants engineered for the production of specific toxin in opposition to herbs or microorganisms may also target the animals that eat them. These may cause the production of new viruses [87]. Genes for protease inhibitors in legumes, goiter genes in canola species, and presser amines in bananas and cyanogens in cassava and lima beans may be turned on and cause an enhance in levels of toxins which can create a vulnerability to the consumers of these harvests.

\subsection{From animals to animals}

The transfer of gene may be to augment farm animals' high yield of milk and meat etc e.g Bovine Growth Hormone enhances milk production in cows and to treat some specific diseases i.e Pigs are treated with recombinant porcine somatotropin (rPST), a growth hormone that raises meat production in pigs, and diminishes the amount of fat and producing low-fat pork but pig meat and by-products is haram for Muslim's and halal animals feed $[87,88]$.

\subsection{Gene products (Enzymes)}

The food industry has taken benefit of the catalytic properties of enzymes as they can boost yield in less time and cost, and improve taste, affect color, and texture and give intelligibility to the end product [89]. Enzymes are used for baking, fruit and vegetable processing, cheese making, beverages, and food ingredient production. Enzymes can be taken from animals, plants, and microorganism. They can be Halal or haram depending upon the source. If the source is Halal then they are considered as Halal otherwise the enzyme will be doubtful. Cheese and whey produced by using animal enzymes are harams if the source is haram animals. Lipase is used for ripening of cheese, lactase is used to improve the digestibility of cheese and Chymosin is an enzyme used for coagulation [90]. The enzymes taken from plants or microorganisms are Halal for consumption like papain is an enzyme extracted from papaya and amylase taken from barley. Pepsin and catalase are extracted from cattle/pig's stomach and bovine liver respectively [91].

Some enzymes are extracted directly either from plants or animals by fermentation while others are biologically engineered. Synthetics enzymes are halalonly when processing and extraction are by halal means. Labelling of enzymes is also an issue of concern. Enzymes from an animal source are not preferably used for feed as halal perspective [92]. Pepsin, lipase, and trypsin are harvested from the pork stomach are haram [93].

\subsection{Techniques to detect pork and lard in feed}

There are a variety of methods to identify and quantify the intensity of mal-practices in feedstuffs. The old way is to determine the ratio between some chemical ingredient and presuming that the ratio is constant in particular feedstuffs. This appears to make logic that any addition in any feedstuff will alter the ratio value or will emphasize an irregularity in its chemical profile. Typically, this is associated with many examinations and the use of chemometrics. [94] 
Whilst a different technique is by probing a specific marker in food products, either chemical ingredient or morphological constituent, which confirms the existence of adulterants in feedstuffs [95]. According to a study the third way is the use of analytical methods resulting from physical analysis by considering whole samples to demonstrate the mal-practices' special effects on the organoleptic properties [96]. These methods depend upon the dissimilarity between the physiochemical constants, and chemical and biological measurements of the minor and major contaminants and the pure oils and fats components [96].

The halal endorsement does not believe exclusively on physical assessment and certification any longer, but also with the most up-to-date high expertise analytical technology. Fourier-transform infrared (FTIR) spectroscopic method was introduced by Che Man \& Mirghani in 2001 for spotting lard in mixtures of other natural fats, such as chicken, lamb and cow and soybean [98]. The utilization indicated that FTIR could qualitatively discriminate between the pure animal's fats and their intermingling. [99] An application of the FTIR in a combined way with attenuated total reflectance (ATR) and partial least square (PLS) to detect pig fat in feedstuffs has been performed [100,101]. Polymerase chain reaction (PCR) has also been modelled for species recognition in meat and fats effectively [102]. In addition to this, Gas Chromatography and High-Performance Liquid Chromatography (HPLC) have been engaged in halal verification of feedstuffs [103]. HPLC scrutinizes the triacylglycerol (TAG) value changes in oil samples due to unprofessional conduct [104]. A rapid technology as an Electronic nose is also helpful for food validation [105]. Its working principle depends upon a two-dimensional olfactory image so-called Vapor print $^{\mathrm{TM}}$ generated by the $\mathrm{zNose}^{\mathrm{TM}}$ that detects lard elements in various fat samples [106].

\subsection{Conclusion}

From the above explanation, it is obvious that Muslim should not only concern on the halal feature of food products but should also broaden their deliberation on the halal animal feed and feeding of animals used for halal food production. This is due to the usual application in feed manufacturing where animal proteins, blood, and animal by-products are used as raw materials in animal feed produced for ruminants, poultry as well as for aquatic animals. Notwithstanding the accessible fatwa from Malaysia, Indonesia, and Brunei that has evidently banned the consumption of al-jallalah and the non-halal feeding practices, no substitute solutions are given by these establishments to be applied by the Muslim consumers, fish trad ers, wholesalers, farmers and feed millers in addressing this issue. The acceptance of al-istibra' or quarantine process, based on the opinions and course of actions given by the Islamic scholars is seen as a good resolution. Proper quarantine process should be conducted as a decontamination method to remove infectivity from jallalah animal to pledge the halalan toyyiban feature of the animal-based products. Thus, the addition of this unconventional solution as orientation and guiding principle to those concerned in the animal feed and livestock industry shall be a sensible effort in putting off Muslims from consuming non-halal food. Above and beyond, those engross in the animal feed industry, including farmers should cooperatively take the accountability to make definite the excellence, wellbeing and halal reliability of animal feed through the accomplishment of HALAL Critical Control Points assessment along the feed supply chain from farm to fork, good animal feeding practices at the farm level, and good manufacturing practices and allocation of animal feed and inputs. .

\section{References}

[1] E. S. Soesilowati, "Business Opportunities for Halal Products in the Global Market : Muslim Consumer Behaviour," Journal of Indonesian Social Sciences and Humanities, 2011.

[2] R. Dodds, “Consumer Choice and Farmers' Markets,” Journal of Agricultural and Environmental Ethics, 2014.

[3] S.G. Alqudsi, "Awareness and Demand for 100\% Halal Supply Chain Meat Products," Procedia - Social and Behavioral Sciences, 2014.

[4] K. G. Grunert, "Current issues in the understanding of consumer food choice," in Trends in Food Science and Technology, 2002.

[5] L. Busch, "Individual choice and social values: Choice in the agrifood sector," Journal of Consumer Culture, 2016.

[6] Z. Shafii, and W.M.N. Wan Siti Khadijah, "Halal traceability framework for halal food production,” World Applied Sciences Journal, 2012.

[7] A. Sulaiman, N. Othman, A.S. Baharuddin, M.N. Mokhtar, and M. Tabatabaei, "Enhancing the Halal Food Industry by Utilizing Food Wastes to Produce Value-added Bioproducts," Procedia - Social and Behavioral Sciences, 2014.

[8] A. Ashraf, F. Abd Rahman, and N. Abdullah, "Poultry Feed in Malaysia: An Insight into the Halalan Toyyiban Issues," in Proceedings of the 3rd International Halal Conference (INHAC 2016), 2018.

[9] N. Saidin, S. Alam, and M. Fadilah Abd Rahman, “Animal Feed: Shariah Perspective,” International Journal of Civil Engineering and Technology (IJCIET), 2018.

[10] A.M. Leman, S. Muzarpar, I. Baba, N.M. Sunar, and R.A. Wahab, "Feedstock for ruminant, non-ruminant and aquatic fish in Malaysia-A review," in AIP Conference Proceedings, 2017.

[11] S. Kayadibi, “A way forward to European standard on Halal food,” Journal of Asian Development Studies, 2014.

[12] P. Brown, R.G. Will, R. Bradley, D.M. Asher, and L. Detwiler, "Bovine spongiform encephalopathy and variant Creutzfeldt-Jakob disease: Background, evolution, and current concerns," Emerging Infectious Diseases. 2001.

[13] T. Habib, "From Farm to Fork - Issues with Fish Farming for Halal Certifying Bodies," http://www.global-businessmagazine.com. 2018.

[14] M.N. Riaz, M.M. Chaudry, M.N. Riaz, and M.M. Chaudry, "Animal Feed and Halal Food," in Handbook of Halal Food Production, 2018.

[15] M.A. Jamaludin, S.A. Rahman, and M.A. Ramli, "Fiqh Analysis On The Legal Status Of Coprophagous Animals : A Special Reference To The Malaysian Aquaculture Industry," in International Fisheries Symphosium, 2011.

[16] E.B. Soliman, and M.A.A. El-Barody, "Physiological responses of dairy animals to recombinant bovine somatotropin: A review," Journal of Cell and Animal Biology, 2014.

[17] C. R.J. and B. D.E., “Update on human health concerns of recombinant bovine somatotropin use in dairy cows," Journal of animal science, 2014.

[18] Veterinary Drugs Directorate, “Questions and Answers - Hormonal Growth Promoters - Canada.ca,” Health Canada Website, 2012.

[19] S. Lahiff, "Species-specific PCR for the identification of ovine, porcine and chicken species in meat and bone meal (MBM)," Molecular and Cellular Probes, 2001.

[20] J.W. Wilesmith, J.B. Ryan, and M.J. Atkinson, “Bovine spongiform encephalopathy: epidemiological studies on the origin.,” The Veterinary record, 1991. 
[21] A.R. Sapkota, L.Y. Lefferts, S. McKenzie, and P. Walker, "What do we feed to food-production animals? A review of animal feed ingredients and their potential impacts on human health," Environmental Health Perspectives. 2007.

[22] J. den Hartog, "Feed for food: HACCP in the animal feed industry," Food Control, 2003.

[23] J. Moreno-Lopez, “Contaminants in feed for food-producing animals,” Polish Journal of Veterinary Sciences, 2002.

[24] C.A. Kan and G.A.L. Meijer, “The risk of contamination of food with toxic substances present in animal feed,” Animal Feed Science and Technology, 2007.

[25] S. Ahmad, "Research and Development on Functional Foods in Malaysia,” Nutrition Reviews, 2010.

[26] K.G. Maciorowski, P. Herrera, F.T., Jones, S.D. Pillai, and S.C. Ricke, "Effects on poultry and livestock of feed contamination with bacteria and fungi," Animal Feed Science and Technology, 2007.

[27] L. Afsah-Hejri, S. Jinap, P. Hajeb, S. Radu, and S. Shakibazadeh, “A review on mycotoxins in food and feed: Malaysia case study,” Comprehensive Reviews in Food Science and Food Safety, 2013.

[28] J. Alexander, “Risk assessment of contaminants in food and feed,” EFSA Journal, 2016.

[29] A.G.J. Tacon and M. Metian, “Aquaculture Feed and Food Safety,” Annals of the New York Academy of Sciences, 2009.

[30] W.S. Khayoon, “Determination of aflatoxins in animal feeds by HPLC with multifunctional column clean-up,” Food Chemistry, 2010.

[31] M. Tieman, “The application of Halal in supply chain management: In-depth interviews,” Journal of Islamic Marketing, 2011.

[32] N.M. Nik Muhammad, F.M. Isa, and B.C. Kifli, "Positioning Malaysia as Halal-Hub: Integration Role of Supply Chain Strategy and Halal Assurance System," Asian Social Science, 2009.

[33] J.M. Soon, M. Chandia, and J. Mac Regenstein, “Halal integrity in the food supply chain,” British Food Journal, 2017.

[34] A. Yngve, A. Oshaug, B. Margetts, M. Tseng, R. Hughes, and G. Cannon, "Editorial: World food summits: What for, and what value?,” Public Health Nutrition, 2010.

[35] FAO, "World Summit on Food Security," in World Food Summit, 2009.

[36] M. Shenstone, “World Population: Why We Should Pay Heed,” International Journal, 2010.

[37] K. Bonne and W. Verbeke, "Religious values informing halal meat production and the control and delivery of halal credence quality," Agriculture and Human Values, 2008.

[38] Food and Agriculture Organisation, "How to Feed the World in 2050," 2009.

[39] Z. Suhaiza, I. Mohammad, A.A. Azmin, and K. Kanapathy, “Halal logistics opportunities and challenges,” Journal of Islamic Marketing, 2017.

[40] R. Abdullah, R. Sabar, and M. Mustafar, “Green Halal supply chain in Malaysian halal food companies: A conceptual framework," International Journal of Supply Chain Management, 2018.

[41] N. Saidin, F. Abd Rahman, and N. Abdullah, "A critical analysis of the legal framework on animal feed in Malaysia: with special reference to the Feed Act 2009," International Journal of Engineering \& Technology, 2018.

[42] B.P. Tan, N. Ishak, and B.M. Ali, “Status on food safety management program for aquaculture products in Malaysia.," Extension Bulletin - Food \& Fertilizer Technology Center, 2013.

[43] M.A.A. Halim, and M.M.M. Salleh, "The possibility of uniformity on Halal standards in organization of Islamic Countries (OIC) country," World Applied Sciences Journal, 2012.

[44] M.Z.S. Hanim, A.Z. Ariffin, A.W. Nabsiah, O. Rosly, and F. Yudi, "Recommendations to strengthen halal food supply chain for food industry in Malaysia," Journal of Agribusiness Marketing, 2010.

[45] M.Z.S. Hanim, A.Z. Ariffin, A.W. Nabsiah, O. Rosly, and F. Yudi, "Recommendations to strengthen,” Journal of Agribusiness Marketing: Special Edition, 2010.

[46] M. Rendueles, F. Moure, A. Fernández, and M. Díaz, "Preliminary Studies on the Processing of Slaughter-House Blood for Protein Recovery,” Resource and environmental biotechnology, 1997.

[47] D.P. Bureau, A.M. Harris, D.J. Bevan, L.A. Simmons, P.A. Azevedo, and C.Y. Cho, "Feather meals and meat and bone meals from different origins as protein sources in rainbow trout (Oncorhynchus mykiss) diets," Aquaculture, 2000.

[48] M.M. Golbaz, S., Farzadkia, M., Vanani, M. and Emamjomeh, "Livestock slaughterhouses waste management in urban environment," International Journal of Human Capital in Urban Management, 2017.

[49] M. Tamin, A. Harun, A. Estim, S. Saufie, and S. Obong, “Consumer Acceptance towards Aquaponic Products," IOSR Journal of Business and ManagementVer. II, 2015.

[50] N. Key and E. Areas, "Food Industry in Malaysia," Food Technology and Resources Based Industries Division, MIDA. 2018.

[51] M.N. Wan Norhana, G.A. Dykes, B. Padilah, A.A. Ahmad Hazizi, and A.R. Masazurah, "Determination of quarantine period in African catfish (Clarias gariepinus) fed with pig (Sus sp.) offal to assure compliance with halal standards," Food Chemistry, 2012.

[52] E. Orban and G. Di Lena, Fish production chain : safety and quality for consumers. 2011.

[53] N. Pelletier and P. Tyedmers, “Feeding farmed salmon: Is organic better?,” Aquaculture, 2007. 
[54] P. Walker, P. Rhubart-Berg, S. McKenzie, K. Kelling, and R. S. Lawrence, “Public health implications of meat production and consumption," Public Health Nutrition, 2005.

[55] E.B. Howard, J.O. Britt, and G.K. Matsumoto, “Parasitic diseases,” in Pathobiology of Marine Mammal Diseases, 2018.

[56] I. Overdevest, “Extended-spectrum $\$ \beta \$$-lactamase genes of Escherichia coli in chicken meat and humans, the Netherlands," Emerging Infectious Diseases, 2011.

[57] T. Aymerich, P.A. Picouet, and J.M. Monfort, “Decontamination technologies for meat products,” Meat Science, 2008.

[58] M. Imran and S. Mahmood, “An overview of human prion diseases," Virology Journal. 2011.

[59] K. Nakyinsige, Y.B.C. Man, and A.Q. Sazili, "Halal authenticity issues in meat and meat products," Meat Science. 2012.

[60] M. Mataragas, P.N. Skandamis, and E.H. Drosinos, "Risk profiles of pork and poultry meat and risk ratings of various pathogen/product combinations," International Journal of Food Microbiology. 2008.

[61] W. Verbeke, F.J.A. Pérez-Cueto, M.D. de Barcellos, A. Krystallis, and K.G. Grunert, "European citizen and consumer attitudes and preferences regarding beef and pork.," Meat science, 2010.

[62] M. Guo, "Quantifying the risk of human Toxoplasma gondii infection due to consumption of fresh pork in the United States," Food Control, 2017.

[63] K.D. Murrell, "Zoonotic foodborne parasites and their surveillance.," Revue scientifique et technique (International Office of Epizootics), 2013.

[64] P.R. Davies, “Intensive Swine Production and Pork Safety,” Foodborne Pathogens and Disease, 2010.

[65] O. Djurković-Djaković, B. Bobić, A. Nikolić, I. Klun, and J. Dupouy-Camet, "Pork as a source of human parasitic infection," Clinical Microbiology and Infection. 2013.

[66] H.R. GAMBLE, “Parasites associated with pork and pork products,” Revue Scientifique et Technique de l’OIE, 2016.

[67] X. Bai, X. Liu, X. Wu, and M. Liu, “Trichinella,” in Biology of Foodborne Parasites, 2015.

[68] A.L. Okello and L.F. Thomas, “Human taeniasis: Current insights into prevention and management strategies in endemic countries,” Risk Management and Healthcare Policy. 2017.

[69] X. Liu, L. Han, P. Veys, V. Baeten, X. Jiang, and P. Dardenne, "An overview of the legislation and light microscopy for detection of processed animal proteins in feeds," Microscopy Research and Technique. 2011.

[70] M.E. Ali, M. Kashif, K. Uddin, U. Hashim, S. Mustafa, and Y. Bin Che Man, "Species Authentication Methods in Foods and Feeds: The Present, Past, and Future of Halal Forensics," Food Analytical Methods, 2012.

[71] B.K. Muflih, N.S. Ahmad, M.A. Jamaludin, and N.F.H. Nordin, “The concept and component of contaminated animals (al-jallalah animals)," International Food Research Journal, 2017.

[72] M.A. Ramli, M.S. Nuba, M.I. Rosele, and A.B. Abdullah, “Perspektif Ibn Taimiyyah Tentang Al-Tasyabbuh Dalam Sambutan Perayaan Bukan Islam(Ibn Taimiyyah Perspective About Al-Tasyabbuh In The Celebration Of Non Muslim Festival)," Umran - International Journal of Islamic and Civilizational Studies, 2018.

[73] A. Abdul Cader, "Islamic challenges to advertising: A Saudi Arabian perspective," Journal of Islamic Marketing, 2015.

[74] A.M. Ramli, A. Jalil, N. Hamdan, A. Haris, and M.A. Abd Aziz, “Fatwa-Fatwa Berkaitan Pengurusan Ekonomi dan Kewangan Masjid," مجلة إدارةو بحوث الفتاوى 2015.

[75] N. Pauzi, S. Man, J. Fiqh dan Usul, A. Pengajian Islam, P. Kanan, and F. dan Usul, "Haiwan Jallalah Dari Perspektif Islam: Analisis Fatwa Malaysia Dan Negara Brunei Darussalam Jallalah Animal from Islamic Perspective: An Analysis on Malaysian and Brunei Darussalam Fatwa," 2015.

[76] M.A. Jamaludin, M.A. Ramli, and S.A. Rahman, "Al-Jallalah : Konsep dan Fatwa Semasa di Malaysia," 2015, مجلة إدارة و بحوث الفتاوى.

[77] M.N.A. Rahman and F.D.M. Laziz, "The importance of quarantine period for the jallalah animals in determining the status of halalan thoyyiban of the meats," Buletin SSMP, 2012.

[78] F. Shaikh and D. Sharma, "Islam and consumption: Religion interpretations and changing consumerism," in Islamic Perspectives on Marketing and Consumer Behavior: Planning, Implementation, and Control, 2015.

[79] S.C. Bhatia, Food biotechnology. 2017.

[80] N. Turan and J. F. Kennedy, “Cereal Biotechnology,” Carbohydrate Polymers, 2003.

[81] J.Z.K. Khattak et al., “Concept of Halal food and biotechnology,” Advance Journal of Food Science and Technology, 2011.

[82] A.I. BOUZENITA, “Change of Creation or Harnessing Nature? The Reception of Biotechnology in the Islamic World,” Islamic Studies, 2009.

[83] M. Izhar Ariff Mohd Kashim, M. Nazir Alias, D. Mardiana Mat Zin, N. Lizza Mohamed Said, A. Dahlan Salleh, and E. Azraai Jamsari, "Istihalah and its Effects on Food: An Islamic Perspective," International Journal of Civil Engineering and Technology (IJCIET, 2018.

[84] L. Amin, S. S. Fairuz, A. L. Samian, M. S. Haron, M. N. Mohamad, and M. Y. Othman, "The permissibility status of plant biotechnology from the Islamic view," Social Sciences (Pakistan), 2012.

[85] A.S. Islam and S. A. Miah, "Transgenic plants: Risks, concerns and effects on ecosystem and human health," Plant Tissue Culture and Biotechnology. 2006.

[86] G.A. Thompson and F.L. Goggin, "Transcriptomics and functional genomics of plant defence induction by phloem-feeding insects," in Journal of 
Experimental Botany, 2006.

[87] M.I.A.M. Kashim, E.A. Jamsari, M.H. Safiai, N.I.M. Adnan, and L.S. Safri, "Genetic Modified Organisms (GMOs) from the Perspective of Science and Maqasid Shari'ah," International Journal of Civil Engineering and Technology, 2018.

[88] A.L. Van Eenennaam, “Genetic modification of food animals," Current Opinion in Biotechnology. 2017.

[89] E. Pichersky and D.R. Gang, “Genetics and biochemistry of secondary metabolites in plants: An evolutionary perspective," Trends in Plant Science. 2000.

[90] C. Schiene and G. Fischer, "Enzymes that catalyse the restructuring of proteins," Current Opinion in Structural Biology. 2000.

[91] A.S. Bawa and K.R. Anilakumar, "Genetically modified foods: Safety, risks and public concerns - A review," Journal of Food Science and Technology. 2013.

[92] E. Ermis, "Halal status of enzymes used in food industry," Trends in Food Science and Technology. 2017.

[93] R. Geisen and W.H. Holzapfel, “Genetically modified starter and protective cultures,” International Journal of Food Microbiology, 1996.

[94] J.M.N. Marikkar, H.M. Ghazali, K. Long, and O.M. Lai, "Lard uptake and its detection in selected food products deep-fried in lard," Food Research International, 2003.

[95] J.M.N. Marikkar, H.M. Ghazali, Y.B.C. Man, T.S.G. Peiris, and O.M. Lai, "Use of gas liquid chromatography in combination with pancreatic lipolysis and multivariate data analysis techniques for identification of lard contamination in some vegetable oils," Food Chemistry, 2005.

[96] C. Cordella, I. Moussa, A.C. Martel, N. Sbirrazzouli, and L. Lizzani-Cuvelier, "Recent developments in food characterization and adulteration detection: Technique-oriented perspectives," Journal of Agricultural and Food Chemistry. 2002.

[97] B. Kowalski, "Sub-ambient differential scanning calorimetry of lard and lard contaminated by tallow," International Journal of Food Science \& Technology, 1989.

[98] Z.A. Syahariza, Y.B. Che Man, J. Selamat, and J. Bakar, "Detection of lard adulteration in cake formulation by Fourier transform infrared (FTIR) spectroscopy," Food Chemistry, 2005.

[99] A. Rohman, Sismindari, Y. Erwanto, and Y.B. Che Man, "Analysis of pork adulteration in beef meatball using Fourier transform infrared (FTIR) spectroscopy," Meat Science, 2011.

[100] J. Hulland, "Use of partial least squares (PLS) in strategic management research: a review of four recent studies," Strategic Management Journal, 2002.

[101] Y.B. Che Man, Y. Erwanto, A. Rohman, and Sismindari, "Analysis of pork adulteration in beef meatball using Fourier transform infrared (FTIR) spectroscopy," Meat Science, 2011.

[102] A.A. Aida, Y.B.C. Man, C.M.V.L. Wong, A.R. Raha, and R. Son, "Analysis of raw meats and fats of pigs using polymerase chain reaction for Halal authentication," Meat Science, 2005.

[103] H. Gika, G. Kaklamanos, P. Manesiotis, and G. Theodoridis, "Chromatography: High-Performance Liquid Chromatography," in Encyclopedia of Food and Health, 2015.

[104] L.R. Snyder, J.J. Kirkland, and J.W. Dolan, Introduction to Modern Liquid Chromatography. 2010.

[105] Y.B.C. Man, H.L. Gan, I. NorAini, S.A.H. Nazimah, and C.P. Tan, “Detection of lard adulteration in RBD palm olein using an electronic nose," Food Chemistry, 2005.

[106] A.M. Marina, Y.B.C. Man, and I. Amin, "Use of the SAW sensor electronic nose for detecting the adulteration of virgin coconut oil with RBD palm kernel olein," JAOCS, Journal of the American Oil Chemists' Society, 2010. 